\title{
COMPUTATIONAL AND STATISTICAL ASPECTS OF DETERMINING SHIP'S POSITION
}

\begin{abstract}
In its mathematical essence, the task of determining ship's position coordinates, is to minimize appropriately defined goal function. This paper proposes to use the method of conjugate gradient for this purpose. The reason is that calculations may be performed in some seconds time because Microsoft and Apache implemented the conjugate gradient method as a tool called the Solver and embedded this tool in their widely offered and popular spreadsheets, namely Excel and the Open Office Calc, respectively. Further in this paper it is shown how to precisely assess errors of ship's position coordinates with the Monte Carlo method that employs the Solver.
\end{abstract}

\section{Keywords:}

determining ship's position, the Least Square method, conjugate gradient, the Monte Carlo method.

\section{INTRODUCTION}

Let us begin with recalling the basics. In its mathematical essence, the task of determining ship's position coordinates $\phi_{o}, \lambda_{o}$, is to employ the Least Square method that consists in minimizing the following goal function [Kopacz et al., 2007].

$$
S\left(\varphi_{o}, \lambda_{o}\right)=\sum_{i=1}^{n}\left\{\left(\varphi_{o}-\varphi_{i}\right)^{2}+\left[\left(\lambda_{o}-\lambda_{i}\right) \cdot \cos \left(\frac{\varphi_{o}+\varphi_{i}}{2}\right)\right]^{2}-d_{i}^{2}\right\}^{2},
$$


where:

$n$

$\phi_{i}, \lambda_{i}$

$i=1,2, \ldots, i, \ldots . n$,

$d_{i}=d_{a i}+\varepsilon$

- measured distances to these reference stations,

$i=1,2, \ldots, i, \ldots n, d_{a i}-$ actual distances,

$\varepsilon$

- an error of measurement.

This error is assumed to be the random variable with expected value equal to zero and the standard deviation equal to $\sigma$ in all measurements. This is a strong assumption that is often violated in practice where standard deviations $\sigma_{i}$ are unequal. If so, it is recommended to minimize the following weighted goal function

$$
S\left(\varphi_{o}, \lambda_{o}\right)=\sum_{i=1}^{n} \frac{1}{\sigma_{i}^{2}}\left\{\left(\varphi_{o}-\varphi_{i}\right)^{2}+\left[\left(\lambda_{o}-\lambda_{i}\right) \cdot \cos \left(\frac{\varphi_{o}+\varphi_{i}}{2}\right)\right]^{2}-d_{i}^{2}\right\}^{2} .
$$

It is a pity that values $\sigma_{i}$ are unknown. And there is no simple remedy for this.

This paper proposes to use the method of conjugate gradient [Fletcher, Reeves, 1964] to minimize (1). The reason is that all the very long calculations needed will be performed in some seconds time. It is possible because Microsoft and Apache implemented the conjugate gradient method as a tool called the Solver and embedded this tool in their widely offered environments, namely Excel and Open Office Calc, respectively.

Further in this paper it is shown how to precisely assess errors of ship's position coordinates with the Monte Carlo method that employs the Solver. The main aim of this paper is to assess how number of reference stations impacts errors of determining of ship's position.

\section{INPUT DATA}

Input data related to reference stations were gathered in Table 1. 
Tab. 1. A list of reference stations

\begin{tabular}{|c|c|c|c|c|}
\hline \multirow{2}{*}{$i$} & \multirow{2}{*}{$\begin{array}{c}\text { Location of } \\
\text { reference station }\end{array}$} & Distance to & \multicolumn{2}{|c|}{ Coordinates } \\
\cline { 3 - 5 } & & $d_{i}[\mathrm{Nm}]$ & $\varphi_{i}$ & $\lambda_{i}$ \\
\hline 1 & Hel & 6,3894 & $54^{\circ} 36,004^{\prime}$ & $18^{\circ} 48,768^{\prime}$ \\
\hline 2 & Gdynia & 7,3418 & $54^{\circ} 32,018^{\prime}$ & $18^{\circ} 32,839^{\prime}$ \\
\hline 3 & Gdańsk & 6,2890 & $54^{\circ} 23,986^{\prime}$ & $18^{\circ} 41,784^{\prime}$ \\
\hline 4 & Górki Zachodnie & 10,1622 & $54^{\circ} 22,233^{\prime} \mathrm{N}$ & $18^{\circ} 46,733^{\prime} \mathrm{E}$ \\
\hline
\end{tabular}

Tab. 2. Actual ship's coordinates

\begin{tabular}{|c|c|}
\hline \multicolumn{2}{|c|}{ Coordinates } \\
\hline$\varphi_{o}^{(0)}$ & $\lambda_{o}^{(0)}$ \\
\hline $54^{\circ} 30,000^{\prime}$ & $18^{\circ} 45,000^{\prime}$ \\
\hline
\end{tabular}

\section{USING THE SOLVER}

Figure 1a shows how the worksheet is arranged of for single use i.e. not for Monte Carlo simulations. Figure $1 \mathrm{~b}$ shows haw the worksheet is arranged for multiple use, i.e. for the Monte Carlo simulation. However for its dimension the figure is located at the end of this paper. Figures are intended to enable readers to acquaint with the worksheet. They may turn out insufficient to prepare fully working worksheet by Excel novices.

Figures $2 \mathrm{a}$ to $2 \mathrm{c}$ show what particular cells of Excel worksheet contain. Figures $3 \mathrm{a}$ and $3 \mathrm{~b}$ instruct how to set up the Solver.

\begin{tabular}{|c|c|c|c|c|c|c|c|c|c|c|c|c|c|c|c|c|}
\hline 7 & A & B & C & D & $\mathrm{F}$ & G & $\mathrm{H}$ & 1 & $\mathrm{~J}$ & K & L & M & $\mathrm{N}$ & 0 & $P$ & Q \\
\hline 1 & \multicolumn{4}{|c|}{ Determinantion of ship's position } & \multicolumn{4}{|c|}{ The least square method used. } & & & & & & & & \\
\hline 2 & & $\phi_{\mathrm{o}}$ & $\lambda_{\mathrm{o}}$ & Task func. & \multicolumn{7}{|c|}{ Minimum of the task function found with the Solver tool } & & & & & \\
\hline 3 & & 3270 & 1125 & $1,72 \mathrm{E}-09$ & \multicolumn{6}{|c|}{ that employs conjugate gradient algorithm. } & & & & & & \\
\hline 4 & \multicolumn{2}{|l|}{ Input data } & & & Bearings & \multicolumn{10}{|c|}{ Steps of calculation } & \\
\hline 5 & $\mathbf{i}$ & $\mathrm{d}_{\mathrm{i}}$ & $\phi_{\mathrm{i}}$ & $\lambda_{i}$ & $\mathbf{i}$ & 1 & 2 & 3 & 4 & 5 & 6 & 7 & 8 & 9 & 10 & \\
\hline 6 & 1 & 6,3894 & 3276,004 & 1128,768 & 1 & $-6,00$ & $-3,77$ & 3273,00 & 54,55 & 0,95 & 0,58 & $-2,19$ & 40,82 & 6,39 & 0,00 & \\
\hline 7 & 2 & 7,3418 & 3272,018 & 1112,839 & 2 & $-2,02$ & 12,16 & 3271,01 & 54,52 & 0,95 & 0,58 & 7,06 & 53,90 & 7,34 & 0,00 & \\
\hline 8 & 3 & 6,2980 & 3263,986 & 1121,784 & 3 & 6,01 & 3,22 & 3266,99 & 54,45 & 0,95 & 0,58 & 1,87 & 39,66 & 6,30 & 0,00 & \\
\hline 9 & & & & & & & & & & & & & & & & \\
\hline 10 & \multicolumn{4}{|c|}{ Tentative ship's coordinates } & \multicolumn{3}{|c|}{ Final ship's coordinates } & & & & & & & & & \\
\hline 11 & $\phi_{\mathrm{o}}$ & 54 & 28 & 3268 & $\phi_{\mathrm{o}}$ & 54 & 30 & & & & & & & & & \\
\hline 12 & $\lambda_{0}$ & 18 & 42 & 1122 & $\lambda_{0}$ & 18 & 45,00 & & & & & & & & & \\
\hline 12 & & & & & & & & & & & & & & & & \\
\hline
\end{tabular}

Fig. 1a. Arrangement of the worksheet for single use 


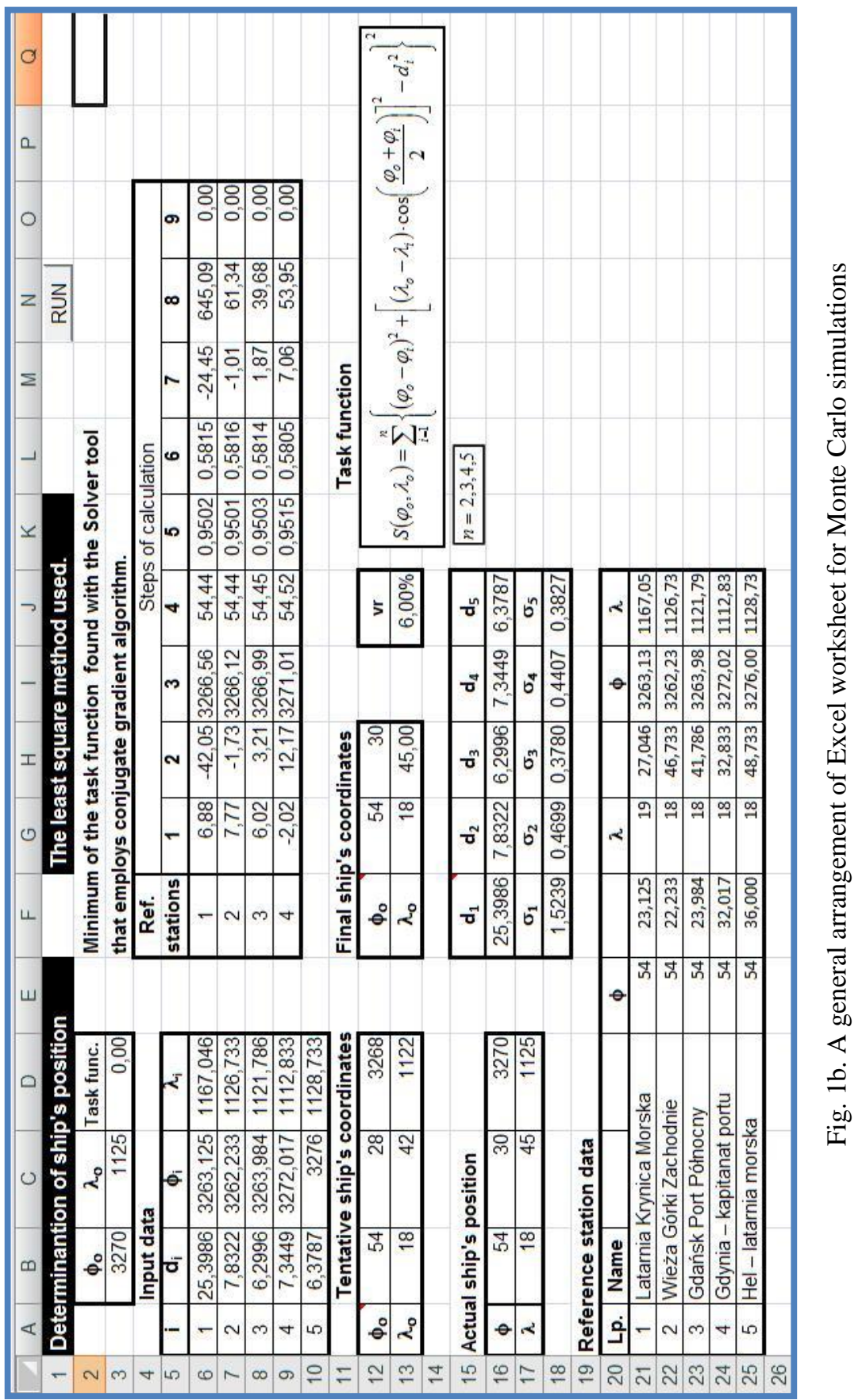




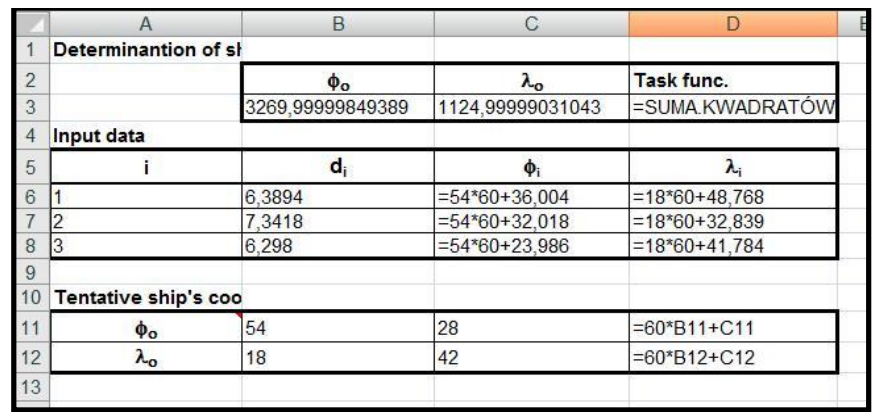

Fig. 2a. The content of cells that comprise input data range

\begin{tabular}{|c|c|c|c|c|c|}
\hline $\mathrm{F}$ & G & $\overline{\mathrm{H}}$ & 1 & J & K \\
\hline \multicolumn{6}{|c|}{ The least square } \\
\hline \multirow{2}{*}{\multicolumn{6}{|c|}{$\begin{array}{l}\text { Minimum of the ta } \\
\text { that employs conj }\end{array}$}} \\
\hline & & & & & \\
\hline Bearings & \multicolumn{5}{|r|}{ Steps } \\
\hline i & 1 & 2 & 3 & 4 & 5 \\
\hline 1 & $=\mathrm{B} \$ 3-\mathrm{C} 6$ & $=C \$ 3-D 6$ & $=(\mathrm{B} \$ 3+\mathrm{C} 6) / 2$ & $=16 / 60$ & $=2^{*} \mathrm{P}()^{*} \mathrm{~J} 6 / 360$ \\
\hline 2 & $=\mathrm{B} \$ 3-\mathrm{C} 7$ & $=C \$ 3-D 7$ & $=(\mathrm{B} \$ 3+\mathrm{C} 7) / 2$ & $=17 / 60$ & $=2^{*} \mathrm{Pl}()^{*} \mathrm{~J} 7 / 360$ \\
\hline 3 & $=\mathrm{B} \$ 3-\mathrm{C} 8$ & $=C \$ 3-D 8$ & $=(B \$ 3+C 8) / 2$ & $=18 / 60$ & $=2^{*} \mathrm{P} I()^{*} \mathrm{~J} 8 / 360$ \\
\hline \multicolumn{6}{|c|}{ Final ship's coord } \\
\hline$\phi_{\mathrm{o}}$ & $=$ ZAOKR.L & $A=M O D(B 3 ; 60)$ & & & \\
\hline$\lambda_{0}$ & $=$ ZAOKR.L & $=\mathrm{MOD}(\mathrm{C} 3 ; 60)$ & & & \\
\hline
\end{tabular}

Fig. 2b. The content of cells that comprise the left segment calculation range

\begin{tabular}{|c|c|c|c|c|}
\hline L & M & $\mathrm{N}$ & 0 & $\mathrm{P}$ \\
\hline \multicolumn{5}{|l|}{ f calculation } \\
\hline 6 & 7 & 8 & 9 & 10 \\
\hline$=\operatorname{COS}(\mathrm{K} 6)$ & $=\mathrm{H} 6^{*} \mathrm{~L} 6$ & $=\mathrm{G} 6{ }^{*} \mathrm{G} 6+\mathrm{M} 6^{\star} \mathrm{M} 6$ & $=$ PIERWIASTEK(N6) & $=\mathrm{B} 6-\mathrm{O} 6$ \\
\hline$=\cos (K 7)$ & $=\mathrm{H} 7^{*} \mathrm{~L} 7$ & $=\mathrm{G} 7^{*} \mathrm{G} 7+\mathrm{M} 7^{*} \mathrm{M} 7$ & $=$ PIERWIASTEK(N7) & $=\mathrm{B} 7-07$ \\
\hline$=\cos (K 8)$ & $=\mathrm{H} 8 * \mathrm{~L} 8$ & $=\mathrm{G} 8^{*} \mathrm{G} 8+\mathrm{M} 88^{*} \mathrm{M} 8$ & $=$ =PIERWIASTEK(N8) & $=\mathrm{B} 8-\mathrm{O} 8$ \\
\hline
\end{tabular}

Fig. 2c. The content of cells that comprise the right segment calculation range

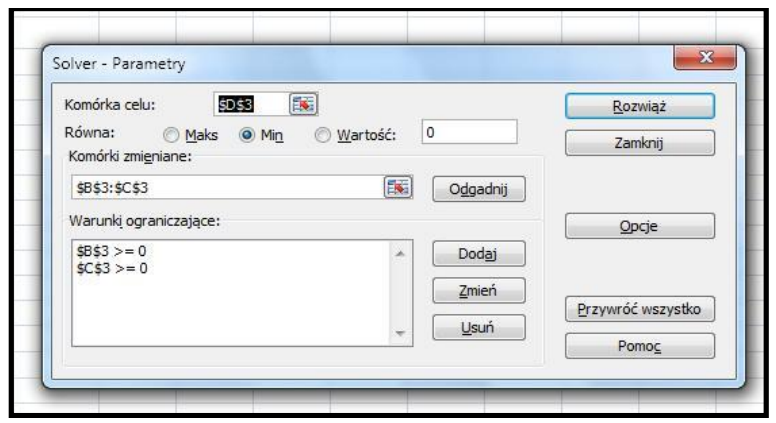

Fig. 3a. Setting the Solver 


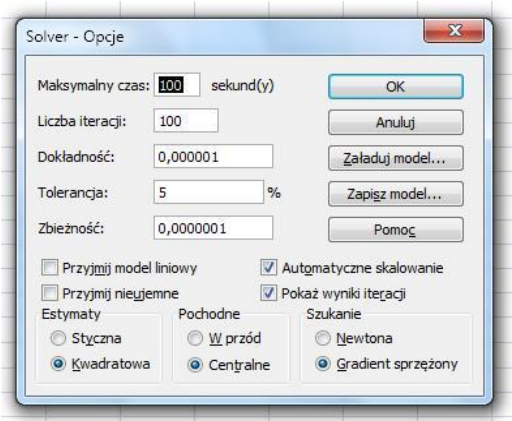

Fig. 3b. Setting Solver options

Figure 4 gives an overview of the goal function having a minimum that has to be localized to determine ship's position. The minimum is situated in a deep valley with steep slopes. It may cause the method to diverge when guesses are taken too far from the solution. A symptom of bad convergence is when a value displayed in the B3 cell is greater than 1E-5. Figure 1a exemplifies a case of good convergence.

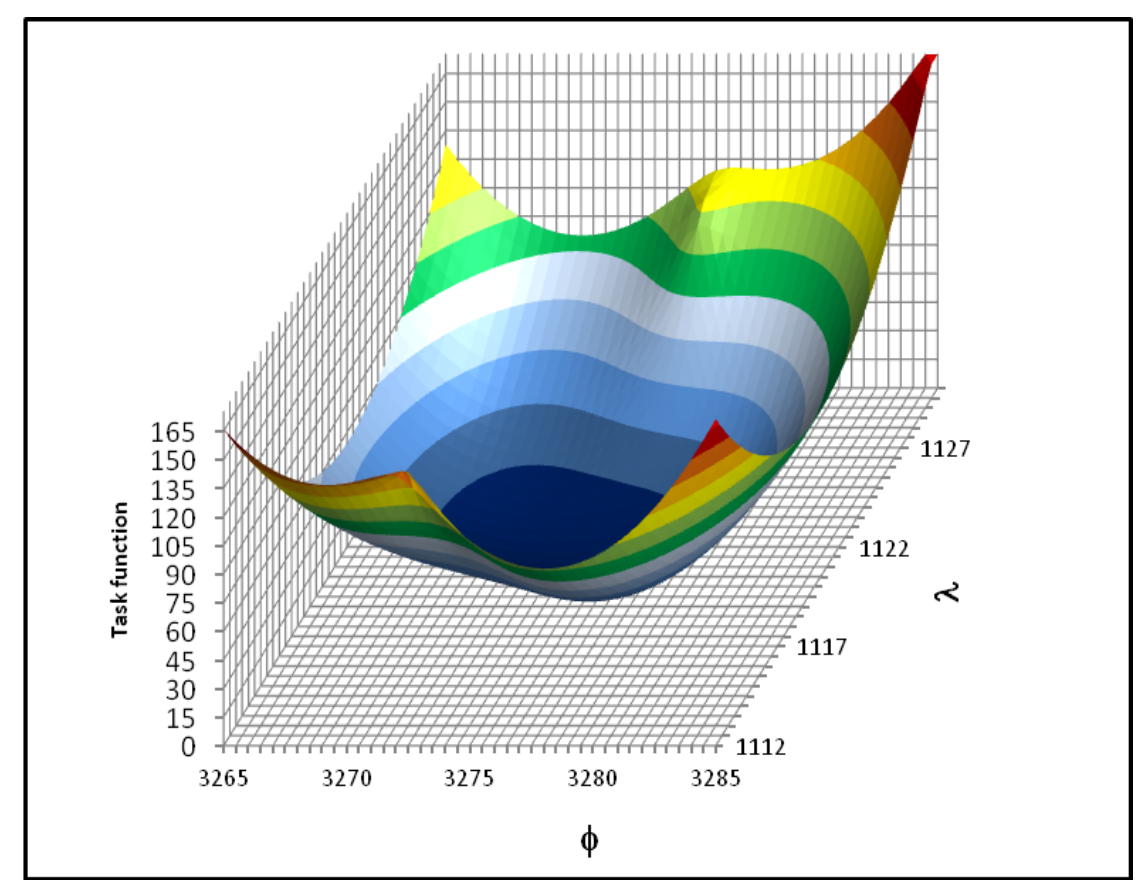

Fig. 4. An overview of the goal function 


\section{AN ERROR ASSESSMENT OF SHIP'S POSITION}

It is assumed that positions of reference stations are purely deterministic variables i.e. are free of error. In contrast distances to reference stations are assumed to be random variables that follow the Normal distribution. Let us remember that Normal distribution has two parameters: the location parameter and the scale parameter. The location parameters of distance distributions are set equal to exact distances. Two variants of calculating the scale parameter are considered. The scale parameter is equated with $\sigma$ introduced in Section 1.

\section{Variant I:}

The scale parameter was assumed to be a fraction of the scale parameter. This fraction is named variability ratio $(v r)$. In the other words

$$
\text { scale parameter }=v r \cdot \text { location parameter },
$$

where $v r=0.15 \%, 0.30 \%, \ldots, 0.75 \%$ were taken in accordance with [IALA 2015].

This variant violates the assumption about $\sigma$ of Section 1 , but reflects what we face in common practice.

Variant II:

The scale parameter is constant

$$
\text { scale parameter }=0.05 \cdot \text { sea mile } .
$$

Variant II fulfill the $\sigma$ - related assumption already considered in Variant I.

Below two VBA (Visual Basic for Application) procedures are presented. The first named Proc01 accomplish the Monte Carlo method. The second named Solver makes Solver to find a minimum of the goal function being repeatedly called by Proc01. Instructions that comprise Proc01 are commented very detailedly. These comments are addressed to novices in practice of the Monte Carlo method.

\section{NEW CONCEPT OF RADAR POSITIONING}

\section{Sub Proc01()}

Dim i As Integer, $j$ As Integer, $k$ As Integer, $v$ As Integer

Dim d0(5) As Single, sd(5) As Single: 'Matrices that contain location and scale parameters. 
$\operatorname{Dim}$ Ss As Single: 'Adder of uniformly distributed random numbers. Used to obtain normal random numbers.

Randomize Timer: 'This statement causes that seeds for internal generator of uniformly distributed random numbers are formed on the basis of data obtained from computer's internal clock.

Application.ScreenUpdating = False: "This statement "freezes" a screen until all the whole Monte Carlo procedure will be completed. It considerably shortens realization of this procedure.

Let $d 0(1)=\operatorname{Cells}(13,10)$ : Let $d 0(2)=$ Cells(13, 11): Let d0(3) = Cells(13, 12): Let $d 0(4)=\operatorname{Cells}(13,13)$ : Let $d 0(5)=$ Cells $(13,14)$ : 'Reading location parameters from the worksheet.

Let $s d(1)=$ Cells $(15,10):$ Let $s d(2)=$ Cells(15, 11): Let sd(3) = Cells(15, 12): Let $s d(4)=$ Cells $(15,13)$ : Let $s d(5)=$ Cells $(15,14)$ : Reading scale parameters from the worksheet.

Range("B21:C1020").Select: Selection.ClearContents: 'Clears block of cells that is a container of Monte Carlo results. For v $=1$ To 1000:

'Looping over subsequent simulations.

Application.StatusBar $=v$ : Shows simulation number I the status bar. Let Cells $(v+20,1)=v$ : 'Writes in subsequent simulation number to the worksheet.

For $i=1$ To 5: 'Looping over reference stations.

Let $S$ s =-6: 'Sets an initial value to the adder (see relevant comment in declarations)

For $j=1$ To 12: 'Looping over summands that form Normal random number.

Let $S s=S s+R n d(1):$ 'Subsequent uniformly distributed random number added.

Next $j$

'Now Ss contains the $N(0,1)$ normal random number i.e. with location parameter equal to zero and scale parameter equal to one.

Let Cells $(5+i, 2) \cdot$ Value $=s d(i){ }^{*} S s+d 0(i)$ : 'Converting $N(0,1)$ into Normal random numbers having location parameters equal to actual distances and scale parameters equal to fractions stated above in the main text.

Next $i$

Let Cells(3, 2) = Cells(16, 8). Value: Cells(3, 3) = Cells(17, 8). Value: Setting

"guesses" i.e. values from which Solver will start looking for a minimum of the goal function.

SOLVER: 'Calling the Solver procedure.

'Solver placed guesses with results

Let Cells $(v+20,2) \cdot$ Value $=$ Cells(3, 2). Value : Results are transferred to the container of Monte Carlo results.

Let Cells $(v+20,3) \cdot$ Value $=$ Cells(3, 3). Value

Next $v$

'The Monte Carlo procedure is ended.

'The set of instructions below sorts results in ascending order. Range ("B21:C1020"). Select 
ActiveWorkbook.Worksheets("Monte_Carlo_3").Sort.SortFields.Clear ActiveWorkbook.Worksheets("Monte_Carlo_3").Sort.SortFields.Add Key:=Range( "B21:B1020"), SortOn:=x|SortOnValues, Order:=xIAscending, DataOption:= $x$ ISortNormal

With ActiveWorkbook.Worksheets("Monte_Carlo_3").Sort

.SetRange Range("B21:C1020")

.Header $=x /$ Guess

. MatchCase $=$ False

.Orientation $=x /$ TopToBottom

SortMethod $=$ xIPinYin

.Apply

End With

Application.ScreenUpdating $=$ True

\section{End Sub}

\section{Sub SOL VER()}

Dim wynik As Long

SolverOptions MaxTime: $=100$, Iterations: $=200$, Precision: $=0.00000001$,

AssumeLinear:=False, StepThru:=False, Estimates:=2, Derivatives:=2,

SearchOption: $=2$, IntTolerance $:=5$, Scaling:=True, Convergence: $=0.000 \overline{1}$, AssumeNonNeg:=False

SolverOk SetCell:="\$D\$3", MaxMinVal:=2, ValueOf:="1", ByChange:="\$B\$3:\$C\$3" Let wynik = SolverSolve(True)

\section{End Sub}

Figures $5 \mathrm{a}$ and $5 \mathrm{~b}$ and relates to Variant I. Figure 6 relates to Variant II.

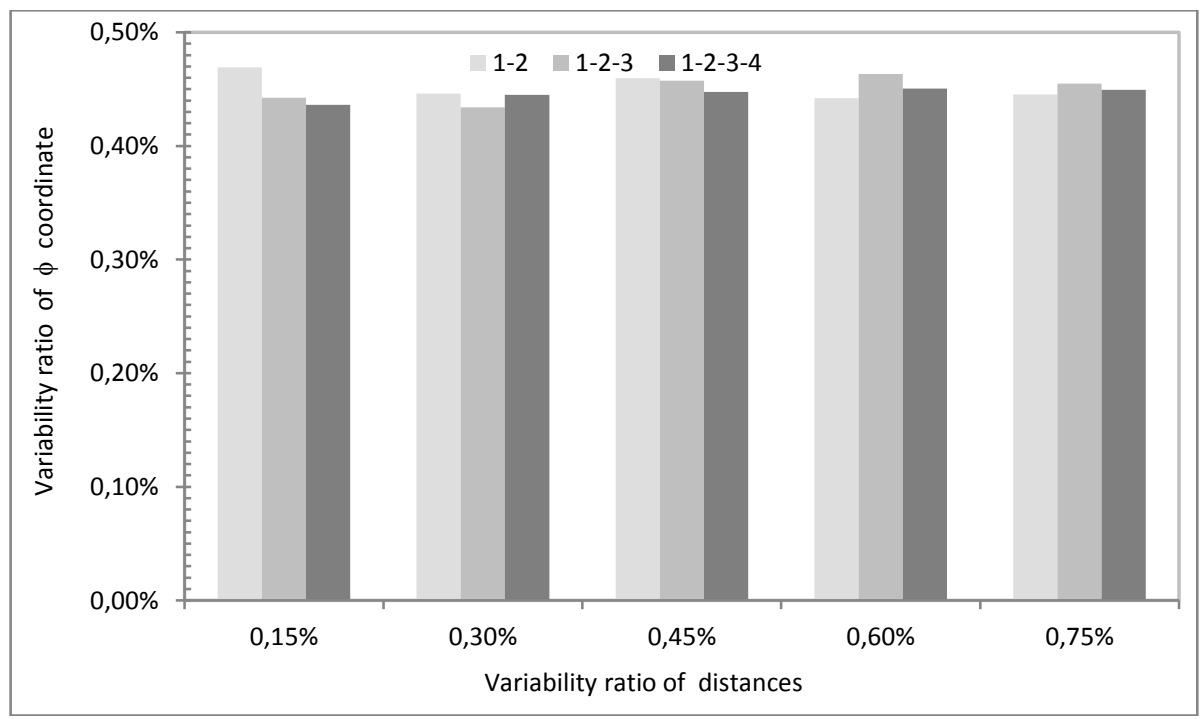

Fig. 5a. The variability ratio of distances versus variability ratio of $\phi$ coordinate 


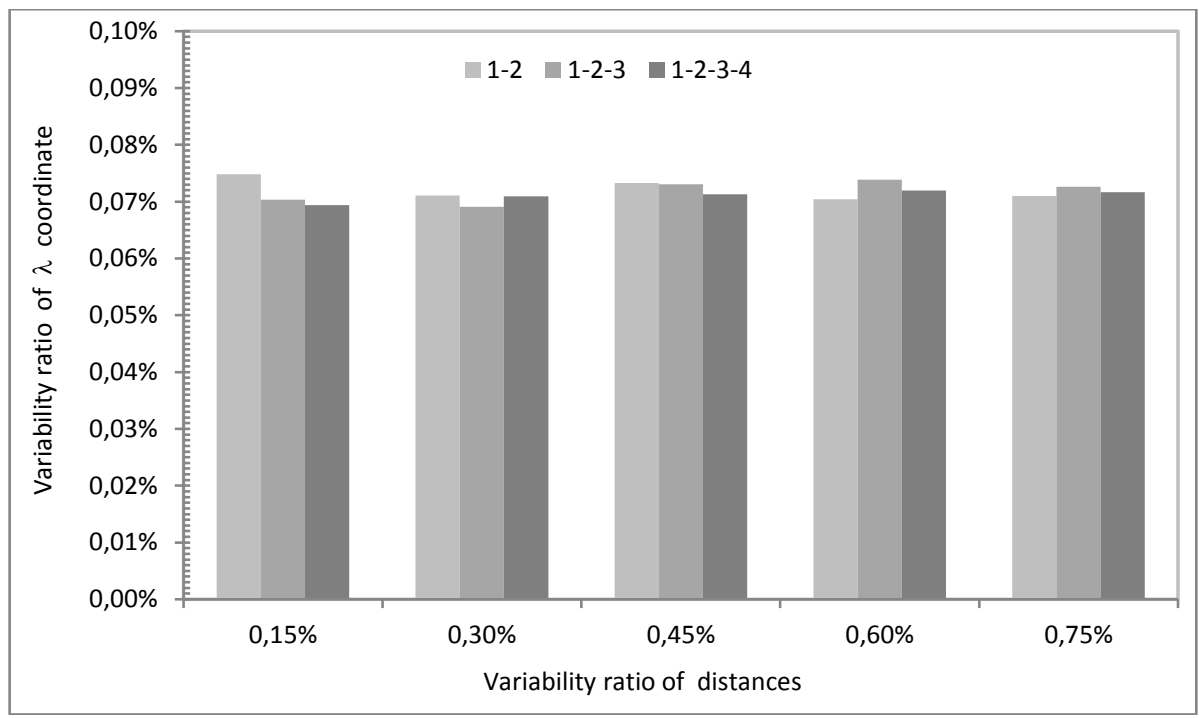

Fig. 5b. The variability ratio of distances versus variability ratio of $\lambda$ coordinate

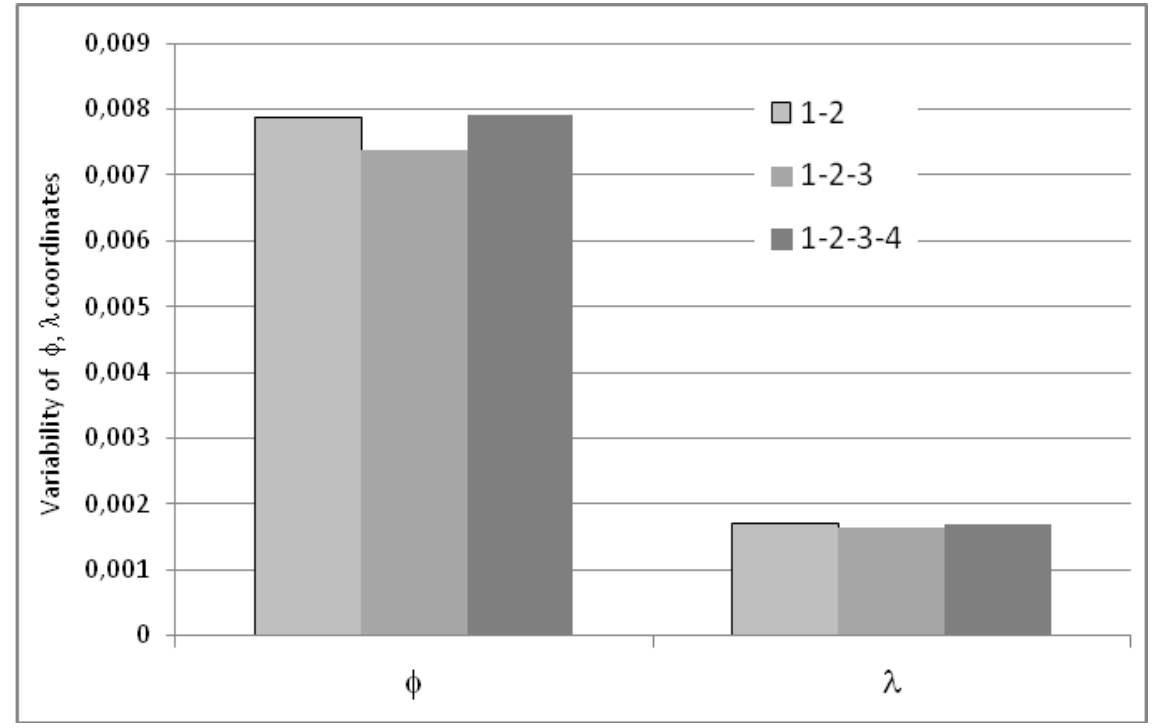

Fig. 6. The variability ratio of $\phi$ and $\lambda$ coordinates

Table $3 \mathrm{a}-3 \mathrm{~d}$ and $4 \mathrm{a}$, 4b contain statistical characteristics of distributions of ship's positions i.e. $\varphi_{o}$ and $\lambda_{o}$ coordinates. In these tables the following notation was used: 
Tab. 3a. Notation used in tables $3 \mathrm{~b}-3 \mathrm{~d}$

\begin{tabular}{|c|l|c|l|}
\hline Symbol & \multicolumn{1}{|c|}{ Meaning } & Symbol & Meaning \\
\hline$\alpha_{1}$ & Mean value & $\gamma_{1}$ & Skewnes \\
\hline $\boldsymbol{\sigma}$ & Standard deviation & $\gamma_{2}$ & Kurtosis \\
\hline
\end{tabular}

Tab. 3b. Statistical characteristics of distributions of ship's positions; reference stations taken into account: $1-2$

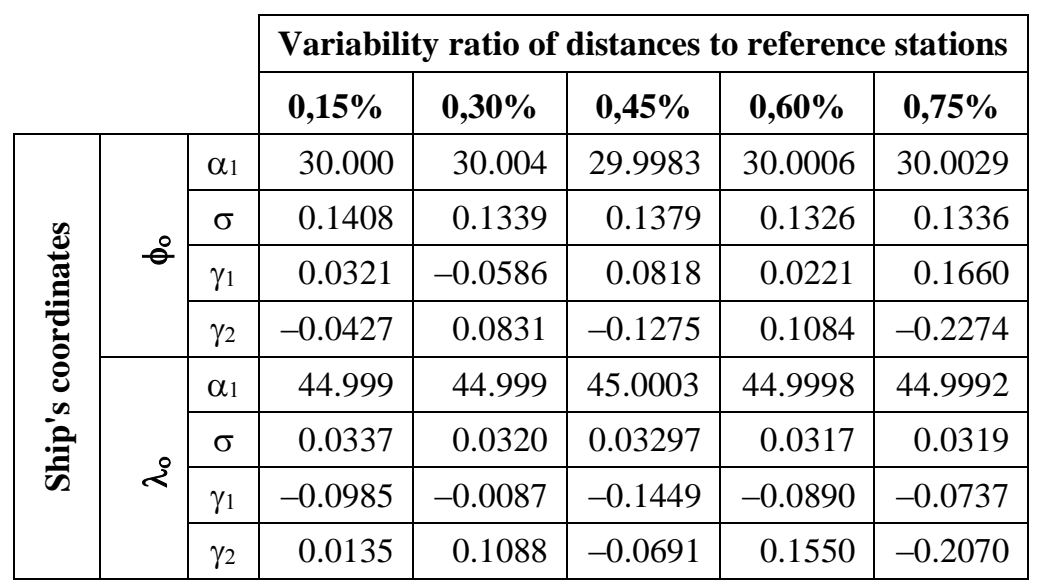

Tab. 3c. Reference stations taken into account: 1-2-3

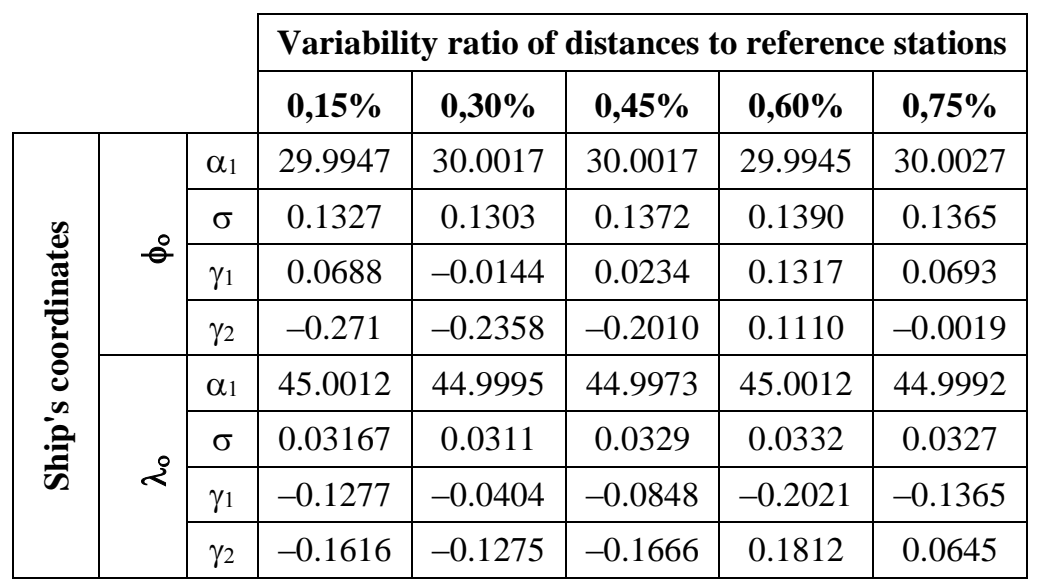


Tab. 3d. Reference stations taken into account: 1-2-3-4

\begin{tabular}{|c|c|c|c|c|c|c|c|}
\hline & \multicolumn{5}{|c|}{ Variability ratio of distances to reference stations } \\
\hline & & & $0,15 \%$ & $\mathbf{0 , 3 0 \%}$ & $\mathbf{0 , 4 5 \%}$ & $0,60 \%$ & $\mathbf{0 , 7 5 \%}$ \\
\hline \multirow{8}{*}{ 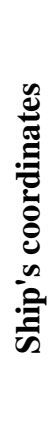 } & \multirow{4}{*}{$\stackrel{\circ}{\circ}$} & $\alpha_{1}$ & 29.9981 & 29.9998 & 29.9998 & 30.0050 & 30.0036 \\
\hline & & $\sigma$ & 0.1381 & 0.1353 & 0.1342 & 0.1352 & 0.1348 \\
\hline & & $\gamma_{1}$ & -0.0006 & 0.0732 & 0.0595 & 0.1085 & 0.1285 \\
\hline & & $\gamma_{2}$ & 0.0733 & 0.02500 & -0.1889 & -0.2612 & 0.1732 \\
\hline & \multirow{4}{*}{2} & $\alpha_{1}$ & 45.0004 & 45.0000 & 45.0003 & 44.9987 & 44.9991 \\
\hline & & $\sigma$ & 0.0312 & 0.0319 & 0.0321 & 0.0324 & 0.0323 \\
\hline & & $\gamma_{1}$ & -0.0634 & -0.1392 & -0.1193 & -0.1688 & -0.1986 \\
\hline & & $\gamma_{2}$ & 0.0967 & 0.0816 & -0.1346 & -0.2041 & 0.2700 \\
\hline
\end{tabular}

Tab. 4a. The coefficient of correlation between $\phi_{o}$ and $\lambda_{o}$ coordinates, Variant I

\begin{tabular}{|c|c|c|c|c|c|}
\hline Ref. & \multicolumn{5}{|c|}{ Variability ratio of distances to reference stations } \\
\hline stations & $\mathbf{0 , 1 5 \%}$ & $\mathbf{0 , 3 0 \%}$ & $\mathbf{0 . 4 5 \%}$ & $\mathbf{0 . 6 0 \%}$ & $\mathbf{0 . 7 5 \%}$ \\
\hline $1-2$ & $-0,996$ & $-0,998$ & $-0,997$ & $-0,995$ & $-0,995$ \\
\hline $1-2-3$ & $-0,998$ & $-0,997$ & $-0,998$ & $-0,999$ & $-0,997$ \\
\hline $1-2-3-4$ & $-0,995$ & $-0,999$ & $-0,997$ & $-0,996$ & $-0,997$ \\
\hline
\end{tabular}

Tab. 4b. The coefficient of correlation $\rho$ between $\phi_{\mathrm{o}}$ and $\boldsymbol{\lambda}_{\mathrm{o}}$ coordinates, Variant II

\begin{tabular}{|c|c|c|c|}
\cline { 2 - 4 } \multicolumn{1}{c|}{} & \multicolumn{3}{c|}{ Ref. stations } \\
\cline { 2 - 4 } \multicolumn{1}{c|}{} & $1-2$ & $1-2-3$ & $1-2-3-4$ \\
\hline$\rho$ & +0.676 & +0.635 & $+0,668$ \\
\hline
\end{tabular}

\section{CONCLUSIONS}

1. A general, qualitative conclusion derived from Figures $5 a, 5 b$ and Figure 6 is rather surprising. When distance errors are so small as [2] requires them to be, then number of reference stations has no noticeable impact on position accuracy. The differences observed on the figures are statistically insufficient and there is no trend observed. This conclusion holds both to Variant I and II. 
2. As one can read from Figures 5a, 5b and Figure 6 the Variability Ratio of position coordinates in Variant I are much greater than in Variant II. One may find as a punishment for violating $\sigma$ related assumption.

3. Measures of skewnes and kurtosis (see Tables $3 \mathrm{a}-3 \mathrm{c}$ ) are very small. It means that position coordinates are random variables that follow (like distance errors) the Normal distribution.

4. The second surprising result is that when one passes from Variant I to Variant II correlation coefficient not only significantly changes its value but even changes its sign!

\section{REFERENCES}

[1] Fletcher R., Reeves C. M., Function minimization by conjugate gradients, 'The Computer Journal', 1964, Vol. 7, Issue 2, pp. 149-154.

[2] IALA Guideline 1111, Edition 1, May 2015.

[3] Kopacz Z., Morgaś W., Urbański J., Evaluation of the accuracy of the ship's position [in Polish], AMW, Gdynia 2007.

Received October 2016

Reviewed April 2017

Published 03.07.2017

\section{ANTONI DRAPELLA}

Polish Naval Academy

Śmidowicza 69 Str., 81-127 Gdynia, Poland

e-mail: adrastat@hotmail.com

\section{WACLAW MORGAŚ}

Polish Naval Academy

Śmidowicza 69 Str., 81-127 Gdynia, Poland

e-mail: w.morgas@amw.gdynia.pl

\section{STRESZCZENIE}

Matematyczna istota wyznaczania współrzędnych pozycji okrętu to minimalizacja odpowiednio zdefiniowanej funkcji celu. Artykuł proponuje wykorzystanie do tego metody gradientu sprzężonego. Dzięki niej obliczenia mogą być wykonane w kilka sekund, ponieważ Microsoft i Apache zaimplementowały metodę gradientu sprzężonego jako narzędzie 
nazwane Solver i umieściły je w swych szeroko oferowanych i popularnych arkuszach kalkulacyjnych: Excelu i Open Office Calc. W artykule pokazano także, jak precyzyjnie określić błędy oszacowania współrzędnych pozycji okrętu metodą Monte Carlo. 